KATARZYNA PĘKACKA-

-FALKOWSKA

ORCID: 0000-0003-2068-7957

BARTOSZ DRZEWIECKI

ORCID: 0000-0002-1697-1114

\title{
Projekt porządku akuszerskiego Towarzystwa Przyrodniczego w Gdańsku (Naturforschende Gesellschaft) z 1781 r.
}

The Project of the Hebammenordnung (1781) by Danzig Research Society

\section{Summary}

The paper comments the Gdańsk/Danzig Hebammen-Ordnung issued in 1781 by the Naturforschende Gesellschaft and presents a scholarly edition of its appendixes. The Danzig Research Society was established in 1743, and in the late $70^{\prime}$ s of the $18^{\text {th }}$ century, at the height of popular and medical enlightenment (Volks- und medizinische Aufklärung), it engaged itself in making improvements in local healthcare system. One of the planned effects of numerous activities of the Society in the above mentioned context was both reform and development of local midwifery, among others creation of a position of the Hebammen-Meister and establishing a list-of-duties for Danzig sworn midwives and their instructor (respectively supervisor).

Słowa kluczowe: Towarzystwo Przyrodnicze, Gdańsk, XVIII w., akuszerstwo, historia medycyny

Key words: Naturforschende Gesellschaft / Danzig Research Society, Danzig, 18th c., midwifery, history of medicine 
Wywodzący się ze środowiska medycznego polscy historycy nauki uważają, że na ziemiach Rzeczypospolitej polsko-litewskiej nie występowały regulaminy akuszeryjne charakterystyczne dla miast zachodnioeuropejskich ${ }^{1}$. O błędności promowanego przez nich twierdzenia świadczy fakt, że już w drugiej połowie XVIII w. w wielkich miastach Prus Królewskich w ramach inicjatyw związanych z realizacją założeń Volks- und medizinische Aufklärung zaczęto tworzyć rozbudowane projekty porządków akuszeryjnych oraz reformować opiekę akuszerską.

W późnych latach 50 . i na początku lat 60 . XVIII w. w Toruniu planowano wprowadzenie specjalnej Hebammen-Ordnung na wzór O poriadocznom uczrieżdienii babiczjewa dieła w polzu obszczestwa (О порядочном учреждении бабичьева дела в пользуобщества), а więc porządku akuszerskiego opracowanego przez Panajotę Condoidiego $\mathrm{w}$ Petersburgu w $1754 \mathrm{r}^{2}$ Osobą odpowiedzialną za przedstawienie projektu nowej ordynacji rajcom toruńskim był lokalny fizyk miejski Johann Thomas Soemmerring, absolwent uniwersytetu lejdejskiego oraz uczeń Hermana Boerhaavego i Bernharda Siegfrieda Albinusa, studiujący w Niderlandach razem z Condoidim oraz z nim się przyjaźniący ${ }^{3}$.

Promowana w Toruniu dwudziestotrzypunktowa Hebammen-Ordnung obejmowała zagadnienia dotyczące m.in. kształcenia przedstawicielek zawodu, wymaganych od nich kompetencji językowych czy zakresu uprawnień przyznawanych kobietom po zakończeniu nauki

${ }^{1}$ Zob. np. M. Wrześniewska, B. Bąk, Historia zawodu położnej i kształtowanie sie opieki okołoporodowej na świecie i w Polsce, „Studia Medyczne” 2012, t. 27, s. 95; E. Matuszewska, Zarys historii zawodu położnej, Warszawa 2012, s. 49-50; E. Waszyński, Historia położnictwa i ginekologii w Polsce, Wrocław 2000, s. 56-58; T. Brzeziński (red.), Historia medycyny, Warszawa 1988, s. 463-464; Z. Łapiński, Stan położnictwa przed powstaniem szkót położniczych, „Polski Tygodnik Lekarski” 1976, t. 31, nr 36, s. 1697-1599; J. Adamski, Rozwój położnictwa w Polsce, „Pielęgniarka i Położna” 1961, t. 3, s. 14-15.

${ }_{2}^{2}$ M. Heine, Medicinisch-Historisches aus Russland, St. Petersburg 1851, s. 61-62, 130-132; W.M. von Richter, Geschichte der Medicin in Russland, Th. 3, Moskwa 1817, s. 332-336.

${ }^{3}$ Johann Thomas Sömmerring przedstawił w Lejdzie dysputację doktorską jako uczeń Albinusa (Dissertatio medica theoretico-practica inauguralis, historim vomicae pulmonum sistens ... Sömmerring, Joann. Thom Lugd. Bat.: apud Conr. Wishoff, 1725), Panajota Condoidi - jako uczeń Boerhaavego (Dissertatio medica inauguralis de morbis aetatu : quam ... ex auctoritate ... Taconis Hajonis van den Honert ..., Lugduni Batavorum: apud Conradum Wishoff Wishoff, Coenraad, 1732). Por. Universitaire Bibliotheken Leiden (UBL), ASF-415, k. 266-267, 303, 306. Kwerenda w bibliotece Uniwersytetu Lejdejskiego była możliwa dzięki realizacji przez K. Pękacką-Falkowską Van de Sande Fellowship. 
i złożeniu przysięgi. Stanowiła także najważniejszy dokument wyznaczający podstawy - dziś powiedzielibyśmy „programowe” - których opanowania wymagano aż do 1793 r. od egzaminowanych przez toruńskich Stadt-Physici kandydatek na urząd akuszerki miejskiej (a więc urzędniczki składającej Hebammen-Eid oraz opłacanej ze środków kamlarii). Wreszcie porządek ten uściślał obowiązki wszystkich kobiet świadczących autoryzowaną pomoc porodową i okołoporodową $\mathrm{w}$ Toruniu, na przedmieściach oraz w jurydyce, a także jednoznacznie wskazywała na konieczność zdobycia przez oficjalne przedstawicielki zawodu rudymentarnej wiedzy anatomicznej oraz, co istotne, chirurgicznej, zwłaszcza w odniesieniu do stosowania prostych instrumentów zabiegowych (np. klisterów, baniek) i medykamentów (głównie przeciwbólowych). Przy czym należy pamiętać, że dzięki Soemmerringowi w Toruniu implementowano tylko część zapisów $O$ poriadocznom..., gdyż dokument autorstwa Condoidiego został tworzony na potrzeby imperium rosyjskiego i nowo powoływanej szkoły dla tamtejszych protopołożnych ${ }^{4}$.

Drugim dyskutowanym w Prusach Królewskich dokumentem tego typu była gdańska ustawa akuszerska z 2 marca 1781 r., opracowana przez członków Naturforschende Gesellschaft, tj. Towarzystwa Przyrodniczego, acz kwestie nadzoru nad akuszerkami poruszano także we wcześniejszych ordynacjach gdańskich, m.in. Medicinal-Ordnung E. E. Raths der Stadt Danzig z 1703 r. $^{5}$ Ze względu na nieprzeprowadzanie kwerend archiwalnych polscy historycy, prawnicy i germaniści uważali, że rękopis porządku z lat 80. XVIII w. albo zaginął, albo uległ zniszczeniu. W rezultacie ostatnią osobą mającą wgląd do manuskryptu miał być - ich zdaniem - Edmund Schumann, który przeanalizował treść ustawy we wczesnych latach 90 . XIX w. ${ }^{6} \mathrm{~W}$ konsekwen-

${ }^{4}$ Edycja porządku wraz z przysięgami i listami obowiązków akuszerek toruńskich w XVIII w. ukazała się w: K. Pękacka-Falkowska, Dyscyplinować i pomagać-torunskie akuszerki miejskie $w$ XVIII w. (kilka uwag na marginesie przysiag i porząków akuszerskich), „Medycyna Nowożytna” 2013, t. 19, nr 2, s. 65-105.

5 Archiwum Państwowe w Gdańsku [dalej: APG], Akta miasta Gdańska [dalej: AmG], 300, 93/44, s. 169-196: Medicinal-Ordnung E. E. Raths der Stadt Danzig, Danzig 1703, s. 191-193 (s. 23-25) [zob. aneks nr 2]. Co interesujące, nadzór fizyków miejskich nad akuszerkami pierwotnie planowano wprowadzić także ordynacją z 29 lipca $1661 \mathrm{r}$. (tamże, s. 75-94), niemniej w ostatecznej wersji dokumentu wykreślono część zapisów mówiących o nadzorze nad kobietami pomagającymi przy porodach (s. 88-89). Ordynacja z 1661 r. jest opracowywana do druku przez K. Pękacką-Falkowską (UMP) i Bartłomieja Sieka (Gdański Uniwersytet Medyczny).

${ }^{6}$ L. Górska, Die Naturforschende Gesellschaft in Danzig und die gemeinnützige Aufklärung, [w:] H. Schmitt, H. Böning, W. Greiling, R. Siegert (red.), Die Entdeckung von Volk, Erziehung und Ökonomie im europäischen Netzwerk der Aufklärung, edition 
cji informacje dotyczące wspomnianego dokumentu, a pojawiające się od ponad stulecia w literaturze przedmiotu, były najczęściej albo komentarzami do pracy Schummana ${ }^{7}$ (choć pełniejszy wgląd w treść gdańskiej Hebammen-Ordnung dawali wcześniej Eduard Otto Dann ${ }^{8}$ i Franz Christian Brunatti ${ }^{9}$ ), albo prostymi wzmiankami o wydaniu wspomnianego porządku bez sygnalizowania jego treści ${ }^{10}$, ewentualnie ekstrapolacją nań postanowień dwóch wcześniejszych ordynacji pruskich - berlińskiej (1765) i królewieckiej (1778) - lub po prostu powieleniem niekompletnych informacji z prac dziewiętnastowiecznych badaczy niemieckich ${ }^{11}$. Żaden z rodzimych uczonych nie sięgnął ad fontes, choć zarówno brudnopis gdańskiego porządku akuszerskiego z $1781 \mathrm{r}$. wraz z tekstem przysięgi dla tzw. mistrza akuszerskiego, jak i kopie części dokumentów zachowały się w zasobie Archiwum Państwowego w Gdańsku w zespole Akt Miasta Gdańska ${ }^{12}$.

$\mathrm{Na}$ fali medycznego oświecenia (medizinische Aufklärung) oraz przemian związanych z postrzeganiem zadań i celów tzw. policji medycznej (medizinische Policey) ${ }^{13}$ Towarzystwo Przyrodnicze w Gdań-

lumière, Bremen 2011, s. 105-106. Tu także w przyp. 36 przegląd autorów literatury polskojęzycznej dotyczącej poruszanego w tym artykule zagadnienia.

7 E. Schumann, Geschichte der Naturforschenden Gesellschaft in Danzig 17431892: Festschrift zur Feier des 150 jährigen Bestehens der Naturforschenden Gesellschaft in Danzig am 2. Januar 1893, Leipzig 1893, s. 21.

${ }^{8}$ E.O. Dann, Topographie von Danzig, besonders in physischer und medicinischer Hinsicht, Berlin 1835, s. 312-315.

9 F.Ch. Brunatti, Die Entbindungs-Lehranstalt von Westpreussen bis zum Jahre 1825, nach seiner Original-Handschrift veröffentlicht von Dr. Rudolf Köstlin, ,SonderAbdruck aus den Schriften der Naturforschenden Gesellschaft in Danzig” 1904, Bd. XI, H. 1/2, s. 41-47. Franz Christian Brunatti (1768-1835) - niemiecki ginekolog, gdańszczanin, w 1804 r. w Gdańsku współorganizował pruską państwową instytucję kształcącą położne (Entbindungs-Lehranstalt). Więcej o nim zob. np. beletryzowana praca: R.F. Brunath, Der Geburtshelfer von Danzig. Nach einer wahren Begebenheit im 18. Jahrhundert, Südwestbuch, Stuttgart 2013.

${ }_{10}$ Zob. np. D. Karkowska, Zawody medyczne, Warszawa 2012, s. 183; E. Waszyński, dz. cyt., s. 70.

${ }^{11}$ J. Bitkowski, Położnictwo w Gdańsku od XVI do końca XIX wieku, AHM, t. XXX, nr 2, s. 170-172. Bitkowski najpierw ekstrapoluje na porządek gdański treść edyktów pruskich, następnie zaś powiela ustalenia Danna, który z kolei kopiuje ustalenia Brunattiego.

12 APG, AmG, 300,93/44, s. 699-710. Fascykul (710 kk.) stanowiący opracowaną jednostkę archiwalną, format: folio. Stan zachowania źródła: dobry. Późnoosiemnastowieczny odpis ordynacji bez elementów dodatkowych (m.in. tytułów poszczególnych paragrafów) por. APG, AmG, 300,93/20, s. 698-702. Dziękujemy dr. P. Paluchowskiemu za wskazanie tej wersji przekazu.

${ }^{13}$ Więcej na temat medycznego oświecenia i policji medycznej zob. np. B. Wahrig, W. Sohn (red.), Zwischen Aufklärung, Policey und Verwaltung. Zur Genese des Medizinalwesens 1750-1850, Wiesbaden 2003; M. Moskalewicz, K. Pękacka-Falkowska, Zdrowieć, zbawiać, produkować. Przekształcenia władzy medycznej w czasach nowo- 
sku pod przewodnictwem Christiana Sendela ${ }^{14}$ podjęło w późnych latach 70. XVIII w. pierwsze próby zreformowania lokalnego akuszerstwa. I właśnie wtedy, w 1779 r., członkowie gdańskiego senatu (czyli rady miejskiej) zażądali od przedstawicieli Towarzystwa, aby ci opracowali odpowiadający ich potrzebom projekt planowanej reformy, a następnie przedłożyli go rajcom na piśmie ${ }^{15}$. Spośród członków Naturforschende Gesellschaft do wykonania tego zadania desygnowano czterech zasłużonych lekarzy, trzymających jednocześnie różne urzędy: Ephraima Krügera ${ }^{16}$, Heinricha Jacoba de la Mottego ${ }^{17}$, Johanna Eilharda Reinicka ${ }^{18}$ i Philippa Adolpha Lampego ${ }^{19}$. Ze względu

żytnych, „Res Publica Nowa” 2013, R. 26, nr 22, s. 8-15; zob. też: numer specjalny poświęcony społecznej historii medycyny w dobie oświecenia czasopisma: „Klio. Czasopismo poświęcone dziejom Polski i powszechnym” 2010, t. 15.

${ }^{14}$ Christian Sendel (1719-1789) - pochodzący z Elbląga gdański medyk i lekarz miejski, studiował w Jenie i Erfurcie, gdzie w 1743 r. wziął udział w dyspucie doktorskiej De Respiratione Difficili. Zajmował się badaniami fizykalnymi (m.in. optyką), pisał poezje, prowadził czasopismo. Był prorektorem gimnazjum akademickiego w Gdańsku. Wielokrotnie wybierany na stanowisko dyrektora Naturforschende Gesellschaft. Więcej o nim zob. np. B. Schulz, Das Danziger Akademische Gymnasium im Zeitalter der Aufklärung, „Zeitschrift des Westpreußischen Geschichtsvereins” 1941, H. 76, s. 25; Fortgesetzte, ergänzte und berichtigte Nachrichten von allen jetzt in Preußen lebenden Schriftstellern und ihren Schriften, „Litterarische Nachrichten von Preußen” 1783, Bd. 2, s. 1-119.

${ }^{15}$ Informacja za F.Ch. Brunatti, dz. cyt. Brak analogicznych zapisów w materiale źródłowym (APG, AmG, 300,1/153 ${ }^{19}$ ).

${ }^{16}$ Ephraim Krüger (1734-1789) - urodzony we Friedland lub w Gdańsku doktor filozofii i medycyny, praktykujący lekarz, promotor inokulacji, od 1780 r. protofizyk gdański, przedstawił w Lipsku dysputę doktorską De nervo phrenico. Był członkiem Societas Latina Jenensis i gdańskiego Naturforschende Gesellschaft. Zob. więcej w: Fortsetzung und Ergänzungen zu Ch. F. Joechers allgemeinem Gelehrten-Lexicon, Bd. 3, Delmenhorst 1810, kol. 907-908; Fortgesetzte, ergänzte und berichtigte Nachrichten...

17 Heinrich Jacob de la Motte (1712-1783) - doktor filozofii i medycyny, praktykujący medyk, syn lekarza Davida Ludwiga, brat Daniela Chodowieckiego, rysownika i pastora kościoła św. Elżbiety, zainteresowany m.in. optyką. H. Eichler, Die Danziger Naturforschende Gesellschaft, 1743-1789, „Jahrbuch für Geschichte der solialistischen Länder Europas” 1984, Bd. 28, s. 68; Fortgesetzte, ergänzte und berichtigte Nachrichten...

18 Johann Eilhard Reinick (1711-1791) - doktor filozofii i medycyny, od 1739 r. praktykujący medyk gdański, wziął udział w Strasburgu w dyspucie doktorskiej $D e$ potu vinoso digestionem impediente magis. Od 1743 r. członek Naturforschende Gesellschaft. Zainteresowany meteorologią i botaniką, prowadził także badania chemiczne leków. Zob. więcej H. Eichler, dz. cyt., s. 49, 70; Fortgesetzte, ergänzte und berichtigte Nachrichten...

19 Philipp Adolph Lampe (1754-1827) - doktor filozofii i medycyny, praktykujący medyk, protofizyk gdański, studiował w Getyndze i Strasburgu, gdzie przedstawił dysputację doktorską De notis ex sepultura in templis. W późniejszych latach podjął studia przyrodnicze i matematyczne w Berlinie. Profesor matematyki w gdańskim gimnazjum akademickim. Członek Naturforschende Gesellschaft i od 1794 r. Kaiserlich Leopoldinisch-Carolinische Akademie der Naturforscher. Zob. więcej E. Kotarski, Gdańska 
na ograniczenia finansowe, długotrwałe dyskusje nad możliwą treścią dokumentu oraz inne pilne obowiązki projekt porządku przedstawiono niemal dwa lata później, w marcu $1781 \mathrm{r}^{20}$, wskazując na konieczność połączenia nauczania teorii z nauczaniem praktycznym, w ten sposób „po części tworząc [gdańskim] uczennicom [akuszeryjnym] możliwość opanowania właściwych rękoczynów [położniczych], po części zaś stopując [ich] rozmaite głuptactwa, oraz pokazując, jak uniknąć łez i niebezpieczeństw" ${ }^{21}$ w trakcie odbierania porodów. Niemniej w zachowanych księgach radzieckich znajdujemy wyłącznie informacje o powstaniu urzędu mistrza akuszerskiego, nie zaś o przygotowaniu ordynacji akuszerskiej (zob. dalej).

Pierwsze uchwytne źródłowo wzmianki o reformie akuszerstwa gdańskiego $\mathrm{w}$ interesującym nas okresie pochodzą ze stycznia $1781 \mathrm{r}$. Co istotne, początkowo gdański „mistrz akuszerski” miał być tylko dodatkową funkcją jednego $\mathrm{z}$ lekarzy ordynaryjnych lub miejskich, a nie odrębnym urzędem. 19 stycznia 1781 r. na posiedzeniu zwykłym gdańskiej rady miejskiej i po wysłuchaniu kilku deputowanych jej członkowie wyrazili bowiem życzenie sporządzenia roty przysięgi dla $\mathrm{He}$ bammen Meister ${ }^{22} .24$ stycznia dyskutowano jednak, czy rzeczywiście mistrz akuszerski powinien być zaprzysięgany. Prezydujący burmistrz uznał bowiem, że dotychczas osoby pełniące podobne obowiązki nie składały przysięgi, gdyż poprzednia Hebammen-Ordnung ${ }^{23}$ nie nakładała takiego obowiązku. Niemniej nie byłoby niczym godzącym w interesy lekarzy, jak uznano w trakcie posiedzenia, gdyby obok zawierania kontraktu (Auftrag) mistrz akuszerski również ślubował ${ }^{24}$. Tego samego dnia, co warte podkreślenia, dyskutowano również o konieczności reformy Physicorum Verordnung obowiązującej od 29 lipca 1661 r. ${ }^{25}$ Sprawy związane $\mathrm{z}$ ochroną zdrowia $\mathrm{w}$ mieście powracały na posiedzeniach zwykłych rady miejskiej w $1781 \mathrm{r}$. jeszcze wiele razy, dotycząc m.in. pojawienia się zarazy w Koronie, prowadzenia inokulacji ${ }^{26}$

poezja okolicznościowa XVIII wieku, Gdańsk 1997, s. 76, 243; Fortgesetzte, ergänzte und berichtigte Nachrichten...

${ }^{20}$ Informacja za F.Ch. Brunatti, dz. cyt. Brak analogicznych zapisów w materiale źródłowym (APG, AmG, 300,1/15320).

${ }^{21}$ F.Ch. Brunatti, dz. cyt., s. 14.

${ }^{22}$ APG, AmG, 300, 31/67a , s. 19.

${ }^{23}$ Najprawdopodobniej odnoszono się do części zapisów Medicinal-Ordnung E. E. Raths der Stadt Danzig publicieret Anno 1703 [zob. aneks nr 2].

${ }^{24}$ APG, AmG, 300, 31/67a , s. 22.

25 Tamże, s. 23. Por. APG, AmG, 300,93/44, s. 75-78 (odpis ordynacji sporządzony w grudniu 1780 r. przez dr. Philippa Adolpha Lampego).

${ }^{26}$ Pierwsze próby inokulacji w Prusach Królewskich prowadził w połowie XVII w. toruński lekarz miejski Simon Schultz. Tegoż, De modo emtionis variolarum ab infectis, 
czy konieczności przygotowania odrębnej roty przysięgi dla chirurga lazaretowego ${ }^{27}$.

I tak, od marca 1781 r. gdańskie Towarzystwo Przyrodnicze miało wyłączne prawo wskazywania trzech kandydatur na nowo utworzony (i niemający odpowiednika w innych miastach Rzeczypospolitej polsko-litewskiej ${ }^{28}$ ) urząd Hebammen-Meister ${ }^{29}$, a więc nauczyciela i nadzorcy akuszerek. Nominowany na to stanowisko medyk miał otrzymywać roczną pensję w wysokości 400 talarów, z czego 3/4 wspomnianej kwoty przekazywałaby mu gdańska kamlaria ${ }^{30}$, natomiast $1 / 4$ - zgodnie z postulatem Gabriela Joachima Weickhmanna ${ }^{31}$ - Towarzystwo Przyrodnicze z legatu Samuela Vercha ${ }^{32}$. Wydaje się jednak, że czterej wymienieni wcześniej gdańscy doktorzy filozofii i medycyny nie tyle opracowali kompletną Hebammen-Ordnung podobną do tych, jakie wydano w drugiej połowie XVIII w. w Rosji czy Prusach ${ }^{33}$, ile raczej przygotowali rozbudowane listy obowiązków dla lokalnych akuszerek i ich przełożonego, które utrzymały moc prawną aż do lat 90. XVIII stulecia ${ }^{34}$.

W 1781 r. kandydatami wskazanymi przez Naturforschende Gesellschaft na urząd Hebammen-Meister zostali dwaj absolwenci uniwersytetu w Jenie Martin Jacob Kubas ${ }^{35}$ i Michael Ludwig

„Miscellanea Curiosa Medico-Physica Academiae Naturae Curiosorum” 1677, Dec. I, A. 8, s. 22-23.

${ }^{27} \mathrm{~Np}$. APG, AmG, 300, 31/67a, s. 50, 53, 59, 227.

${ }^{28}$ Wcześniej w wielkich miastach Prus Królewskich funkcje edukacyjne i kontrolne nad akuszerkami miejskimi pełnili fizycy miejscy oraz - w wybranych przypadkach - chirurdzy radzieccy. Zob. więcej: K. Pękacka-Falkowska, Dyscyplinować..., dz. cyt., passim.

${ }^{29}$ Urząd ten pojawiał się od lat 20. XVIII w. w krajach niemieckojęzycznych. Zob. np. B. Spitzer, Der Zweite Rosengarten: Eine Geschichte Der Geburt, Staude 1999, s. $117 \mathrm{i} \mathrm{n}$.

${ }^{30}$ Informacja za F.Ch. Brunatti, dz. cyt. Brak analogicznych zapisów w materiale źródłowym (APG, AmG, 300,12/190-194; APG, AmG, 300,10/288, k. 13).

${ }^{31}$ Fortgesetzte..., dz. cyt., s. 108-109.

32 F.Ch. Brunatti, dz. cyt., s. 15-16. Por. E. Schumann, dz. cyt., s. 15; E.O. Dann, dz. cyt., s. 312-315, J. Bitkowski, dz. cyt., s. 172-173.

${ }_{33}$ Zob. np. Instruction der Medicinischen Cantzeleÿ vor die verordnete und beeÿdigte Heb-Ammen, [w:] K. Pękacka-Falkowska, Dyscyplinować..., dz. cyt., s. 96-105; No. XXIII. Instruction vor die Hebammen in den kleinen Staedten Und auf dem Platten Lande 1778, „Register über die Königl. Preuss. und Kurfürstlich Brandenburgische in den Jahren 1776, 1777, 1778, 1779, und 1780. Ergangene Edikte, Patente, Mandate und Haupt-Verordnungen" s.d., s. 3553-3556.

${ }^{34}$ J. Bitkowski, dz. cyt., s. 174 i n.

35 Martin Jacob Kubas (1724-1794) - gdański medyk, studiował w Jenie, gdzie przedstawił dysputację doktorską De Vigiliis. Zob. więcej: Fortgesetzte, ergänzte und berichtigte Nachrichten..., dz. cyt. 
Wittwerck ${ }^{36}$ oraz wykształcony w Halle Johann Ludwig Kulmus ${ }^{37}$ należący do słynnego rodu gdańskich anatomów i lekarzy. Spośród nich senat wybrał i zaprzysiągł 23 marca $^{38}$ na urząd Kubasa. Do jego obowiązków jako mistrza akuszerskiego należało kształcenie przyszłych położnych oraz kontrola przedstawicielek zawodu działających w mieście, na przedmieściach oraz w jurydyce ${ }^{39}$.

Zgodnie ze świadectwem F.Ch. Brunattiego, który powrócił do Gdańska w 1796 r. po niemal siedmioletniej peregrinatio medica, pierwszy w historii Gdańska mistrz akuszerski miał ograniczyć swoje dotychczasowe aktywności zawodowe, aby skupić się na zajęciach prowadzonych dla kandydatek do zawodu oraz móc odwiedzać wraz $\mathrm{z}$ nimi ubogie ciężarne $\mathrm{w}$ miejscach, w których te ostatnie mieszkały. Kubas nie miał także przyjmować od brzemiennych i członków ich rodzin wynagrodzenia za pomoc przy porodach - zarówno o przebiegu prawidłowym, jak i patologicznym - tak aby rodzące umożliwiły w ten sposób dziewczętom dozorowanym przez medyka naukę rękoczynów położniczych właśnie na nich. Dziewczęta podlegające mistrzowi akuszerskiemu miały być przezeń instruowane również w zakresie prowadzenia badań fizykalnych oraz budowy anatomicznej ciała kobiety. W przypadku budowy anatomicznej mistrz prowadził dodatkowo demonstracje na ciałach niewiast zmarłych w gdańskim lazarecie. Nauka u mistrza trwała pół roku, niemiej te uczennice, które chciały zostać w przyszłości zaprzysiężonymi akuszerkami miejskimi (a nie ordynaryjnymi), miały obowiązek uczestniczyć w zajęciach Hebammen-Meister przez trzy lata. $\mathrm{W}$ tym czasie co roku podchodziły także do egzaminów. Natomiast co cztery lata od objęcia urzędu akuszerskiego musiały powtarzać u mistrza kurs półroczny. W przypadku śmierci

${ }^{36}$ Michael Wittwerck (1720-1800) - gdański medyk urodzony w słynnej rodzinie ludwisarzy, uczeń Johanna Adama Kulmusa, studiował filozofię i medycynę w Jenie, gdzie wziął udział w dyspucie doktorskiej De diagnosi inflammatione verarum. Grosses vollständiges Universal Lexicon aller Wissenschaften und Künste, welche bisshero durch menschlichen Verstand und Witz erfunden und verbessert worden, Leipzig-Halle 1748, Bd. 57, s. 1984-1985. Zob. więcej: Fortgesetzte, ergänzte und berichtigte Nachrichten..., dz. cyt.

37 Johann Ludwig Kulmus (1754-1791) - gdański medyk, przedstawił w Halle dysputę doktorską De Cavto Regiminis Calidi Usu (1768).

${ }_{38}$ APG, AmG, 300,31/67a, s. 76. Brak informacji w równoległej serii źródeł: APG, AmG, 300,1/153 $3^{21} ; 300,5 / 185^{16,17}$.

${ }^{39}$ Danzig, „Berichte der allgemeinen Buchhandlung der Gelehrten” 1781, St. 8, s. 689-690; Nachrichten und Neuigkeiten, „Friedrich August Weiz der Arzneygelahrheit und Wundarzneykunst Doktor, derer Churf. Sächs. Ämter Tautenburg und Eckartsberga, wie auch der Stadt Freyburg an der Unstrut, Physicus, und Practicus zu Naumburg, Neue Auszüge aus Dissertationen für Wundärzte” 1782, Bd. 15, s. 212. 
ubogiej ciężarnej, rodzącej albo położnicy Hebammen-Meister miał obowiązek wezwać wszystkie uczennice oraz akuszerki miejskie, aby omówić z nimi przyczyny trudnego porodu i/lub śmierci kobiety oraz - jeśli było to możliwe - przeprowadzić sekcję pokazową na matce (i niekiedy płodzie/noworodku), nie pobierając przy tym żadnych opłat wnoszonych czy to w pieniądzu, czy to w naturze. Dziewczęta miały jedynie uiszczać należne za przyjęcie na naukę oraz za egzaminy, do których podchodziły; środki te dzielono następnie między mistrza akuszerskiego i dwóch fizyków miejskich, wchodzących w skład komisji egzaminacyjnych. Zgodnie ze słowami Brunattiego w $1781 \mathrm{r}$. wprowadzono także drobne kary pieniężne dla kandydatek na akuszerki oraz akuszerek miejskich za ich błędy i różne niedbalstwa, które to środki rozdzielano później między ubogie ciężarne, aby „Zwiększyć liczbę okazji, w których ubogie godzą się na to, aby stać się przedmiotami nauczania" ${ }^{40}$. Co ważne, obowiązki w zakresie kształcenia akuszerek miały także zaprzysiężone akuszerki miejskie, które również powinny były zabierać ze sobą uczennice do porodów, aby te mogły z bliska obserwować czynności geschworene Hebamme ${ }^{41}$.

Co jednak istotne, w $1781 \mathrm{r}$. nie stworzono w Gdańsku ani szkoły, ani zakładu położniczego (Gebaeranstalt), w których mistrz akuszerski mógłby prowadzić zajęcia praktyczne. Właśnie dlatego, jak stwierdził Brunatti, podstawy akuszerstwa w Gdańsku przez kolejną dekadę wyznaczały zapisy instrukcji dla akuszerek i instrukcji dla ich mistrza, które realizowano w kontekstach pozaszpitalnych ${ }^{42}$.

Zatwierdzone 2 marca 1781 r. obowiązki mistrza akuszerskiego zostały pogrupowane w pięć kategorii: kształcenie akuszerek i kandydatek do zawodu (par. 1), pomoc przy trudnych porodach (par. 2), orzecznictwo w przypadku urodzeń martwych albo śmierci noworodka (par. 3), prowadzenie dysekcji w ramach odbywających się w miesiącach zimowych lekcji dla przedstawicielek zawodu (par. 4) oraz przyjmowanie młodych kobiet na naukę (par. 5). Powoływany na urząd Hebammen-Meister lekarz zobowiązywał się do wypełniania wymienionych obowiązków, składając przysięgę, przy czym o nowo stworzonym stanowisku gdańskiego nauczyciela i nadzorcy akuszeryjnego entuzjastycznie wyrażali się twórcy pierwszego tomu „Archiv der medizinischen Polizei und der gemeinnützigen Arzneikunde”. Redaktorzy tego lipskiego czasopisma wprost pisali:

\footnotetext{
40 Tamże, s. 16.

41 Tamże, s. 15-16. Por. J. Bitkowski, dz. cyt., s. 172.

42 F.Ch. Brunatti, dz. cyt., s. 14-16.
} 
„[w] Gdańsku z inicjatywy Towarzystwa Przyrodniczego powstało nowe przedsięwzięcie mające na celu poprawę stanu [lokalnego] akuszerstwa; i nie tylko zapoznano [gdański magistrat] z nowym projektem porządku akuszerskiego, którego plan ww. Towarzystwo przedłożyło [rajcom], lecz także wybrano mistrza akuszeryjnego, który dwa razy w tygodniu prowadzi wykłady dla akuszerek i który otrzymuje od magistratu wynagrodzenie w wysokości 100 dukatów"43.

W tym samym czasopiśmie niedługo później omawiano również głośną pracę Bernarda Christiana Fausta Gedanken über Hebammen und Hebammenanstalten auf dem Lande (1784), nawiązując w trakcie przedstawiania głównych zadań urzędu nauczyciela i nadzorcy akuszeryjnego, o którym pisał autor książeczki, do sytuacji panującej w Gdańsku od 1781 r. ${ }^{44}$

Dalece bardziej rozbudowana niż lista obowiązków HebammenMeister była lista obowiązków akuszerek gdańskich i uczennic akuszeryjnych obejmująca 24 punkty - o jeden więcej niż w przypadku porządku przedstawianego w Toruniu dwie dekady wcześniej.

Po pierwsze, instrukcja gdańska regulowała zachowanie akuszerek względem mistrza akuszeryjnego (par. 1), względem samych siebie (par. 2), względem innych akuszerek (par. 3) oraz względem ciężarnych, rodzących i położnic (par. 4,5). Obok procedur postępowania w przypadku trudnych porodów (par. 5) nowym dokumentem regulowano także procedury w sytuacjach wystąpienia śmierci pozornej oraz konieczności interwencji chirurgicznej (par. 6, 8), kwestie stosowania przez akuszerki leków wewnętrznych (par. 7), opieki nad położnicą i jej dzieckiem (par. 9), narodzin tzw. potworków, a więc płodów z wadami rozwojowymi (par. 10), uczestnictwa w lekcjach prowadzonych przez mistrza akuszeryjnego (par. 11, 12, 13) czy udzielania chrztu z wody w sytuacji zagrożenia życia noworodka (par. 14). Kolejna grupa przepisów odnosiła się do struktury zawodowej akuszerek gdańskich, rozróżniając zaprzysiężone akuszerki (geschworene $\mathrm{He}$ bamme) od tzw. akuszerek zwykłych bądź ordynaryjnych (gewöhnliche Hebamme) (par. 15), a także przedstawiając obowiązki akuszerek zaprzysiężonych względem uczennic (Lehrtochter) (par. 16) i na odwrót (par. 17). Instrukcja mówiła również o warunkach przyjęcia na naukę akuszerstwa, w tym o konieczności wniesienia opłaty (par. 18), organizacji zajęć lekcyjnych, egzaminach i otrzymywaniu atestacji

${ }^{43}$ Kurze Nachrichten (Nr. 23), „Archiv der medizinischen Polizei und der gemeinnützigen Arzneikund” 1783, Bd. 1, s. 351-352. Tłum. K. Pękacka-Falkowska.

${ }^{44}$ Rezensionen, „Archiv der medizinischen Polizei und der gemeinnützigen Arzneikund” 1785, Bd. 3, s. 347-352, Register (D.). 
(par. 19, 20, 21, 22), obowiązku złożenia przysięgi po zdaniu egzaminu końcowego ${ }^{45}$ (par. 23) oraz konieczności dalszego kształcenia przez kolejne trzy lata od uzyskania patentu (par. 24).

Obie późno osiemnastowieczne gdańskie instrukcje - dla akuszerek i dla ich przełożonego - są dziś cennym świadectwem ukazującym przemiany $\mathrm{w}$ organizacji pomocy okołoporodowej $\mathrm{w}$ wielkich miastach Prus Królewskich w dobie oświecenia. Te nieznane do tej pory dokumenty wraz ze źródłami toruńskimi mogą pomóc zrozumieć, jak w drugiej połowie XVIII w. w wielkich miastach Prus Królewskich, a następnie w XIX w. na ziemiach Rzeczypospolitej pod zaborami dokonywała się profesjonalizacja akuszerstwa, czyli przekształcanie się pewnego zespołu czynności i umiejętności związanych z urzędem akuszerskim (Amt) i służbą akuszerską (Dienst) w zawód (Beruf) ${ }^{46}$.

\title{
Aneksy
}

W trakcie edycji rękopisów zachowano oryginalna pisownie i brzmienie wyrazów oraz rozwinięto skróty.

\author{
Aneks nr 1: Zachowane fragmenty gdańskiej Hebammen-Ordnung \\ $z 1781 r$. \\ Źródło: APG, AmG, 300,93/44, s. 699-708ª.
}

[s. 699] Pflichten des Hebammen-Meisters

Schule $\mathrm{u}[\mathrm{nd}]$ Unterricht 1. Der Hebammen-Meister muß wochentl[ich] 2 Stunden aussetzen in welchen er die gantze Hebammen Kunst Stuckweise den Hebammen $u[n d]$ Lehrtöchtern nach einem guten LehrBuche deutlich, faßlich und ohne Entgeld vorträgt $\mathrm{u}$ [nd] lehrt, $\mathrm{u}$ [nd] sich bemühen die Lehr-Töchter in der so schweren $u[n d]$ wichtigen Kunst des Unterschlagens so viel als möglich zu üben.

45 Polskie tłumaczenie niemieckiej roty przysięgi dla gdańskich akuszerek miejskich z 1697 r. (APG, AmG, 300, 1/95, s. 97-98) przytaczali m.in. S. Sokół (tenże, Medycyna $w$ Gdańsku w dobie odrodzenia, Wrocław 1960, s. 226) i za nim J. Bitkowski (dz. cyt., s 164-165). Pozostałe gdańskie przysięgi akuszerskie zachowały się w: APG, AmG, 300,R/L,1, s. 118-119; 300,R/L,2, s. 20; 300,R/L,4, s. 92-92, 234 (zob. aneks nr 3).

${ }^{46}$ Szerzej o tym procesie zob. K. Pękacka-Falkowska, Dyscyplinować..., dz. cyt., s. 67; G. Böhme, Wissenschaftliches und lebensweltliches Wissen am Beispiel der Verwissenschaftlichung der Geburtshilfe, [w:] N. Stehr, V. Meja (red.), Wissenssoziologie (Sonderheft 22 der KZfSS), Opladen 1981, s. 445-463.

${ }^{a}$ W przekazie APG, AmG, 300, 93/20, s. 698-699 brak tytułów poszczególnych paragrafów. 
Hilfleistung 2. Er ist verpflichtet in schweren Fallen bey Schwangeren, Gebahrenden oder Entbundenen auf der Ruff der ${ }^{\mathrm{b}}$ Hebamme, bey Tage und Nacht, bey Reichen u[nd] Armen, sich nach Möglichkeit willig zur Hülfe finden zu laßen, es sey durch einer guten Rath oder auch eigne Handanlegung, welcher Hülfe er denen erweißl[ich] Armen ohnentgeldl[ich] leisten muß.

Tödtliche Fälle 3. Bey einem tödtl[ich] abgelaufenen Fall muß er die Hebammen zusammen ruffen laßen, ihnen diesen Fall anzeigen, erklären, die Ursache der Schwierigkeit der Geburt $\mathrm{u}$ [nd] des Todes ihnen begreif[lich] machen, sie darüber belehren, $u[n d]$ wenn es sich thun läßt, dieses alles durch die Zergliederung des Leichnam $[\mathrm{m}] \mathrm{s}$ noch deutlicher machen.

Jahr[lische] anatomische Zergliderung 4. Er ist schuldig jeden Winter in eignigen Stunden auf dem öffent[lischen] anatomischen Theater an einem weibl[ichen] Leichnam der ihm auf sein Ansuchen ohne Entgeld aus dem hiesiegen Lazareth angewiesen wird, die weibl[iche] Geburts Theile allen Hebammen u[nd] Lehrtöchtern öffentl[ich] u[nd] ohne Entgeld zu zergliedern.

[s. 700] Was für Personen soll er als Lehrtochter annehmen

5. Er soll keine Person als Lehrtochter annehmen, von der er sich nicht uberzeugt hat, daß sie einen guten Lebenswandel geführt, $\mathrm{u}$ [nd] überdies mit denen so wohl zu würckl[ich] gründlicher Erlernung, als auch künftig nützlicher Ausübung der Hebammen Kunst erforderl[ich] Eigenschaften versehen ist. d[ie] 2. Mart[ii] 1781.

b Skreślony wyraz: geschworenen. 
$\operatorname{Eid}^{\mathrm{a}}$ :

Ich N.N. schwere, daß ich nach meinen besten Kräften jederzeit bemüht seyn werde, die mir vorgeschriebene $u[n d]$ obliegende Pflichten eines Hebammen Meisters aufs genauste und sorgfältigste zu erfüllen, $u[n d]$ der von ein Rath gemachten Verordnung nach ihrer jetzigen Abfaßung sowohl als auch der etwan Künftig zu machen den Abänderung $u[n d]$ Zusätzen derselben in allen Stücken genau $u[n d]$ gewissenhaft nachzuleben, so wahr.

\section{[s. 703] Pflichten der Hebammen}

Verhalten der Heb-

ammen

á gegen den Hebam-

men Meister

$\beta$ gegen sich

$\gamma$ gegen einander

1. Die Hebammen sollen dem Hebammen-Meister in allem was zu ihrer Wissenschaft gehört folgen $\mathrm{u}[\mathrm{nd}]$ ihm allegebührende Achtung bezeigen.

2. Auch sollen sie mäßig u[nd] nüchtern seyn.

3. Im Fall, daß zwey Hebammen in ihren Geschäften bey einer Frau zusammen kommen, sollen sie sich friedlich gegen einander verhalten, auch soll keine die andre verachten, verkleinern oder zu verdrengen, $u[n d]$ sich in ihre Stelle zu setzen suchen.

$\delta$. gegen schwangere, 4. Jede Hebamme soll sich, wenn sie bey einer gebahrende oder entbundene

1) ohne Verzug $\mathrm{zu}$ kommen

2) sie nicht zu verlaßen

3) bey schweren $\mathrm{u}[\mathrm{nd}]$ langsamen Gebürten x. nicht übertreiben e. keinesI nstruments sich bedienen den Hebammen-Meister rufen schwangeren, gebahrenden oder entbundenen Frau zu Hülfe geruffen wird, so gleich bey Tage und Nacht, bey Armen u[nd] Reichen, willig zur Hülfe finden laßen, $\mathrm{u}[\mathrm{nd}]$ diejenige Frau bey der sie sich einmahl befindet, sie sey arm oder reich, durchaus nicht verlaßen $\mathrm{u}[\mathrm{nd}] \mathrm{zu}$ einer anderen ${ }^{\mathrm{b}} \mathrm{zu}$ welcher sie geruffen wird hingehen.

5. Sie sollen ferner keine kreisende Frau weder mit Worten noch mit Artzeneyen zur Geburts Arbeit nöthigen $\mathrm{u}[\mathrm{nd}]$ übertreiben um Balde laß zu kommen, noch weniger sich ceines Instruments bedienen, es wäre denn in Gegenwart des Geburtshelfers oder Hebammen-Meisters sondren wem die Arbeit nicht [s. 704] fortgehen will oder sich sonst ${ }^{\mathrm{d}}$ Schwierigkeiten finden, der ${ }^{\mathrm{e}}$ oder $^{\mathrm{f}}$ Hebammen-Meister sogleich zur Hülferuffen laßen. ${ }^{\mathrm{g}}$ 
4) bey scheunigem Tode der Schwangern oder Gebährend[en]

5) in Ansehung innerliche Arzneyen

6) In Ansehung der todten oder todtscheinenden Frucht u[nd] der Nachgeburt

7) In Ansehung des Besuchs nach der Entbindung

8) In Ansehung der monstreusen $\mathrm{u}[\mathrm{nd}]$ Mißgebürten.

$\varepsilon$ Besuchung der anatomischen demonstrationen

1. Zusammenkunft bey tödtlichen Fällen
6. Auch soll jede Hebamme verbunden seyn sogleich den Geburtshelfer oder Hebammen-Meister zu ruffen, im Fall, daß entweder eine zur rechten Zeit gebährende Frau schleunigstest als wovon ein Schlagfluß, starcke Krämpfe etc. zuweilen die Ursache seyn können, und das gut stehende Kindnoch bey der Frau ist, oder aber wenn sich auch ein solcher plötzlicher Todsfall bey einer noch Schwangere ereignet, die zuweilen eine todtscheinende Frau noch wieder zum Leben gebracht oder ${ }^{\mathrm{h}}$, wenn dieses nicht ist doch das Kind entweder durch eine Künstliche Geburt oder ander Operation vielleicht am Leben erhalten werden kan.

7. Ferner soll keine Hebamme innerliche Artzeneyen verordnen, blos gantz geringe und ihnen vom Hebammen-Meister gelehrte Mittel mögen ihnen im Fall der Noth zu geben erlaubt seyn.

8. Auch sollen isie keine ihnen glaublich todte Frucht oder Nachgeburt von einer Frau durch treibende Mittel oder mit ${ }^{j}$ Gewalt ausführen sondern sogleich die Hülfe des Hebammen-Meisters suchen, ${ }^{k}$ auch ${ }^{1}$ die ihnen vom letztern gelehrte Mittel wie man versuchen muß ein solches Kind wieder [s. 705] zum Leben zu bringen mit allem Fleiß und Embsigkeit anwenden.

9. Jede Hebamme die einer Gebahrenden in der Geburt beygestanden muß in den ersten Wochen nach der Geburt täglich aufs wenigste einmahl[ig] und in den folgenden nach Nothdurft, so ofte und so lange zu der Kindbetterin gehen, sie sey reich oder arm bis Mutter $\mathrm{u}[\mathrm{nd}] \mathrm{Kind}$ sich völligwohl befinden.

10. Alle monstereuse $\mathrm{u}[\mathrm{nd}]$ wiedernatürl[iche] gebildete Kinder müßen die Hebammen beym Hebammen-Meister anzeigen.

11. Imgleichen sind alle derjenigen die das Hebammen Geschäfte ausüben wollen verpflichtet den offentl[ichen] jährlichen anatomischen Zergliederungen des Hebammen-Meisters auf dem hiesigen anatomische Theater im Winter bey zu wohnen fals sie nicht durch Amts-Geschäfte davon abgehalten werden.

12. Auch werden sie sich willig finden laßen $\mathrm{u}$ [nd] kommen wenn der Hebammen-Meister sie nach einem tödtlich abgelaufenen falle zu deßen Erläuterung zusammen beruffen läst, wenn sie gleichfals nicht durch Amtsgeschefte abgehalten werden. 
$\kappa$. Wer zusammenruffen soll

[s. 706] $\Lambda$. wegen der Nothtaufe

Unterschied der Hebammen
13.Und die jüngste Lehrtochter wird verpflichtet seyn sie alle auf Geheiß der Hebammen-Meisters zusammen zu ruffen.

14. Jede Hebamme muß von einem Prediger sich in der richtigen Art die Nothtaufe zu verrichten unterweisen laßen.

15. Die kunftighin vor Ein Rath anzunehmende ${ }^{\mathrm{m}} 3$ geschworne Hebammen werden $\mathrm{auch}^{\mathrm{n}}$ in der Folge die seit langer Zeit beliebte Besoldungen jährlich erhalten und sich den damit festgesetzten Pflichten unterziehen, diese heißen Stadtgeschworne Hebammen und können das gewöhnliche Hebammen Schild mit der Stadt Wappen bezeichnet aushängen. Die übrigen geschowornen Hebammen heißen bloß geschworne Hebammen u[nd] haben in ihren Schilde nicht das Wappen der Stadt.

Practischer Unter- 16. Jede geschworne Hebamme ist verpflichtet eine richt der Lechrtoch- Lehrtochter auf Anordnung des Hebammen-Meiter von der geschwor- sters zur Seite zu nehmen u[nd] sie von den nöthinen Hebammen

Pflicht der Lehrtochter sowohl ${ }^{\circ}$ gegen die geschworne Hebamme ${ }^{\mathrm{p}}$ als auch überhaupt

[s. 707] Was eine Person die die Hebammen Kunst erlernen will überhaupt zu thun hat ${ }^{\mathrm{q}}$

Untersuchung Einschreibe-Geld Touchirgeld

Erlernung der Kunst gen Handgriffen der Hebammen Kunst practice zu unterrichten bey füllen u[nd] Personen wo es thunlich ist, gegen eine billige Belohnung von Seiten der Lehrtochter.

17. Jede Lehrtochter ist dagegen verpflichtet der geschwornen Hebamme in Sachen ihrer Kunstgeziemend zu gehorchen, ihr Handreichung zuleisten $\mathrm{u}[\mathrm{nd}] \mathrm{ihr}$ überhaupt geziemende Achtung zu erweisen, auch soll sie sich nicht unternehmen blos allein $\mathrm{u}$ [nd] ohne Aufsicht einer geschworenen Hebamme einer gebährenden Frau beyzustehen.

18. Wenn eine Person die Hebammen-Kunst um selbige hier auszuüben erlernen will, so muß sie sich deswegen bey dem Hebammen-Meister melden $\mathrm{u}$ [nd] sich seiner Untersuchung, ob sie dazu tüchtig ist unterwerfen, $u[n d]$ wenn selbiger sie dazu für tüchtig befunden, so zahlt sie erstl[ich] an den Hebammen-Meister Einschreibe Geld 3 f[1.] u[nd] dann zur Belohnung der schwangere Persohnen, die sich zu den so nöthigen solcher ${ }^{r}$ Übungen brauchen laßen etwas, mehr oder weniger, je nach dem mehr oder weniger Lehrtöchter sind, welcher der HebammenMeister bestimmen muß.

19. Denn geht sie so lange in die vom HebammenMeister wochentl[ich] zu haltende Vorlesungen biß sie ihre Wissenschaft volkom[m]enhat. 
Tentamen des Hebammen-Meisters

Examen

Bitte bey Ein

Hochw[eisen] Rath um die Erlaubniß zur Praxis

Eyd

Fortgesetzte ${ }^{\mathrm{u}}$ Ansuchung der Vorlesungen des Hebam[m] en-Meisters
20. Glaubt sie sich denn fertig in ihrer Wissenschaft zu seyn, so läst sie sich vom Hebammen-Meister tentuire $\mathrm{u}[\mathrm{nd}]$ wenn dieser sie für tüchtig befund[en] so erhält sie darüber $u[n d]$ über den von ihm genoßenen Unterricht ein Attestat u[nd] Bezahlt dafür $3 \mathrm{fl}$.

21. Mit diesem meldet sie sich bey denen Herren Physicis $u[n d]$ wird von dem HebammenMeister in Gegenwart der hiezu zu ernennend[en] Obrigkeitl[iche] Personen u[nd] derer Herren Physicorum examiniert, doch so, dieses die Herren Physici wenn es ihnen beliebt auch fragenaufwerfen können.

22. Hat sie sich in diesem Examine gut $u[n d]$ ihre Kunst wohl ${ }^{\mathrm{s}}$ habend gezeiget so erhält sie darüber einen Schein mit demselben meldet sie sich bey Ein Hochw[eisen] Rath bittet um die Erläubniß in dieser Stadt die Hebammen tKunst ausüben zu können.

23. Wenn sie diese Erläubniß erhalten leistet sie den Hebammen Eid.

24.Und dann muß sie noch 3 Jahre lang einerv jede öffent[ichen] Vorlesung des Hebammen-Meisters besuchen, wofern ihre Umstände ihr solches verstatten.

Act[um] d[ie] 2. Mart[ii] 1781.

a Wyraz podkreślony

b-b Nadpisane: oder oraz wyraz nieczytelny.

c Skreślony wyraz: unterstehen.

d Nadpisane nad skreślonym, nieczytelnym wyrazem.

e Podkreślony linia przerywana i skreślony wyraz: Geburtshelfer.

f Wyraz nadpisany.

g Skreślony fragment: und sich in allen nach.

h Skreślony wyraz: aber.

i Skreślony fragment wyrażenia: die Heb[...].

Wyraz nadpisany.

k Skreślony wyraz: sondern.

- Wyraz nadpisany.

m Skreślony fragment: $\mathrm{u}[\mathrm{nd}] \mathrm{zu}$ besoldende.

n Wyraz nadpisany.

- Wyraz nadpisany.

p Skreślony fragment wyrazu: besen[...].

q Skreślony fragment: u[nd] er.

r Lekcja niepewna.

Wyraz nieczytelny.

Skreślony fragment wyrazu: Vesen[...].

Wyraz nadpisany.

Lekcja niepewna. 
Projekt porządku akuszerskiego Towarzystwa Przyrodniczego w Gdańsku...

Aneks nr 2: Fragment Medicinal-Ordnung E[hrbares] E[hrfarenes] Raths der Stadt Danzig z 1703 r. odnoszacy się do kontroli fizyków miejskich nad akuszerkami

Źródło: APG, AmG, 300,93/44, s. 169-196 (wklejka): Medicinal-Ordnung E.E. Raths der Stadt Danzig publiciret Anno 1703, s. 191-193 (s. 23-25).

[s. 191] XI. Hebammen sollen examiniret werden: Und weiln auch an erfahrnen und geschickten Hebammen ein grosses gelegen / massen an ihrer Verrichtungen mehrentheils zweyer menschen Leben und Gesundheit / und an jedem Versehen ihr eigen Gewissen und Seeligkeit / Ehre und guter Nahme hänget Und dahero grosse Vorsichtigkeit und guter wolauffgeräumter Verstand / nebst unvermüdeten Fleiß Und Treue erfordert [s. 192] wird; Als sollen von nunan weder in / noch außer der Stadt / so weit dero Jurisdiction gehet/einige Hebammen geduldet werden / es sey dann / daß sie vorgängig von den Physicis examiniret / und darauf in behörlichen Eyd und Pflicht genommen worden.

XII. Hebammen Ambt / und von ihren Curiren: Welche nun solchergestalt recipiret seynd/sollen ihre Pflichten bey vorfallender Gelegenheit treulich wahrnehmen / und werder in= noch nach der Geburth ichtwas an sich erwinden lassen / so von einer sorgfältigen und Gewissenhafften Hebammen könte desideriret weden; Sonsten aber sollen sie sich des Curirens bey dem Frauenzimmer / Sechswöcherinnen und Kindern/zugeschweige andern Personen / gäntzlich enthalten; Es währe dann in höchsten Nothfall bey Wöcherinnen und neugebohrnen Kindern / da so bald kein Medicus zu erhalten / ein gemeines / simples und unschädliches Mittel / welches sie aus der Apothekenbereiten liessen / als welches ihnen so dann abgefolget werden kann.

XIII. Hebammen sollen keine verdächtige Medicament geben: Ubrigens so wie den Hebammen / krafft dieses / auffs schärffste untersaget wird / sich auf keinerley weise zu unterstehen / einiger Person / sie sey ledig oder verehliget / einig medicament, Tranck / Pulver / oder wie dasselbe Nahmen haben mag/dadurch eine Frucht in Mutterleibe könne gefährdet/getödtet/früh oder spät/lebendig oder todt / abgetrieben werden/zu bereiten/oder bereiten zu lassen/auszugeben/oder Rath dazu zu geben / bey Verlust ihrer Bedienung/Ehre und anderwärtiger [s. 193] schwerer Straffe / an Geld und Gut / ja nach befinden / an Leib und Leben; Also sollen sie hiemit auch gehalten seyn / wann ihnen verdächtige Personen vorkommen / de bey 
ihnen unziemlichen Rath und Hülffe suchen / solches / nachdem sie sich der Umbstände / so viel thunlich / erkundiget / alsofort der Obrigkeit anzumelden / damit dem besorgenden Unheyl vorgebeüget / und dergleichen Gottlosigkeit zur gebührenden Straffe gezogen werden könne.

\section{Aneks nr 3: Gdańskie przysięgi akuszerskie - roty} Źródto: APG, AmG, 300, R/L, 1, s. 118-11947.

[s. 118] Der Hebammen Eydt.

Ich N. schwere, daß ich in bedienung der schwanger[en] Frauen in der Zeit der Geburth /:wozu mich die Obrigkeit gesetzet hat:/ nicht allein schuldig seyn will allem möglichen fleiß [s. 119] anzuwenden, damit so woll die Mutter alß Kind mit allem was dazu gehöret, woll versehen, und nicht verwahrlaset werden möge, sonde[r]n wenn auch bey schwanger[en] und gebuhrenden Frauen einige Unrichtigkeit und Verbrechen Vermercket würde, solches ungesaumet anzeigen. So wahr mir Gott helffe und sein heiliges Wort.

Źródło: $A P G, A m G, 300, R / L, 4$, s. $234^{48}$.

[s. 234] Der Hebammen Eydt. aus E.E. Raths Schlus 22. Jul. A. 1662.

Ich N. schwere, daß ich zu denen, schwangeren frauen, so werden Hülffe bebegehren, jeder Zeit zu Tag und Nacht, unverdrüßlich kommen, und ihnen in der Geburth, $\mathrm{u}[\mathrm{nd}]^{49}$ wo sie es bedürffen, zuvor, oder hernach trewlich und fleißigrathen, helffen und dienen will, ohne Geitz und übersetz, dem armen gleich dem Reichen damit durch Gottes hulffe Mutter und Kind, bey leben, und unVerletzten Leibe erhalten werde. Auch soll und will ich treulich acht geben, daß kein frembdes kind betrüglich untergeschoben, noch andere Verwahrlosung oder schädliche abtreibung $d[e r]$ frucht gebraucht werde. In schweren nothfällen und Lebens gefahr will ich neben meinen besten fleisse bey Zeiten ermachen, daß man d[er] H[err] Prediger und Artznenen Doctoren, oder der Wund Ärtzte Trost und Hülffe gebrauche, und die H[eilige] Tauffe nicht versäume. Wenn ich auch zu gefangene Persohnen, durch Obrigkeit befehl gebrauchet werde, will ich ohne belohnung solches thun, wie solches bisshero gebräuchlich gewesen

${ }^{47}$ Wersje równoległe (ze zmodernizowanym zapisem): $A P G, A m G, 300, R / L, 2$ (s. 20) $i$ L,4 (s. 92-93).

48 Por. APG, AmG, 300,1/95, s. 97-98 (przysiega zindywidualizowana z czerwca 1697 r., składana przez niejaka Katarzynę: „Catharina, Johann Blanckensages Haußfraw").

${ }^{49} \mathrm{~W}$ wersji $A P G, A m G, 300,1 / 95$ wyraz: oder. 
und alle unrechte Geburth ${ }^{50}$ treulich und fleißig der Obrigkeit melden und offenbahren. So wahr mir Gott helffe etc. ${ }^{51}$

\section{Bibliografia}

Adamski J., Rozwój położnictwa w Polsce, „Pielęgniarka i Położna” 1961, t. 3.

Bitkowski J., Położnictwo w Gdańsku od XVI do końca XIX wieku, „Archiwum Historii Medycyny” 1967, t. XXX, nr 2.

Böhme G., Wissenschaftliches und lebensweltliches Wissen am Beispiel der Verwissenschaftlichung der Geburtshilfe, [w:] von N. Stehr, V. Meja (red.), Wissenssoziologie (Sonderheft 22 der KZfSS), Opladen 1981.

Brunatti F.Ch., Die Entbindungs-Lehranstalt von Westpreussen bis zum Jahre 1825, Nach seiner Original-Handschrift veröffentlicht von Dr. Rudolf Köstlin, „Sonder-Abdruck aus den Schriften der Naturforschenden Gesellschaft in Danzig” 1904, Bd. XI, H.1/2.

Brzeziński T. (red.), Historia medycyny, Warszawa 1988.

Dann E.O., Topographie von Danzig, besonders in physischer und medicinischer Hinsicht, Berlin 1835.

Danzig, „Berichte der allgemeinen Buchhandlung der Gelehrten“ 1781, St. 8.

Eichler H., Die Danziger Naturforschende Gesellschaft, 1743-1789, „Jahrbuch für Geschichte der sozialistischen Länder Europas” 1984, Bd. 28.

Fortgesetzte, ergänzte und berichtigte Nachrichten von den ausserhalb in ihrem Vaterlande lebende Preuß. Schriftstellern und ihren Schriften, „Litterarische Nachrichten von Preußen” 1783, Bd. 2.

Górska L., Die Naturforschende Gesellschaft in Danzig und die gemeinnützige Aufklärung, [w:] von H. Schmitt, H. Böning, W. Greiling, R. Siegert (red.), Die Entdeckung von Volk, Erziehung und Ökonomie im europäischen Netzwerk der Aufklärung, edition lumière, Bremen 2011.

Heine M., Medicinisch-Historisches aus Russland, St. Petersburg 1851.

Karkowska D., Zawody medyczne, Warszawa 2012.

Kurze Nachrichten (Nr. 23), „Archiv der medizinischen Polizei und der gemeinnützigen Arzneikund" 1783, Bd. 1.

Łapiński Z., Stan położnictwa przed powstaniem szkót położniczych, „Polski Tygodnik Lekarski” 1976, t. 31, nr 36.

\footnotetext{
50 Tamże: und die selbe bedienen sollte.

51 Tamże dopisany passus: und sein heiliges Wort.
} 
Matuszewska E., Zarys historii zawodu położnej, Warszawa 2012.

Moskalewicz M., Pękacka-Falkowska K., Zdrowieć, zbawiać, produkować. Przekształcenia władzy medycznej w czasach nowożytnych, „Res Publica Nowa” 2013, R. 26, nr 22.

Nachrichten und Neuigkeiten, „Friedrich August Weiz der Arzneygelahrheit und Wundarzneykunst Doktor, derer Churf. Sächs. Aemter Tautenburg und Eckartsberga, wie auch der Stadt Freyburg an der Unstrut, Physicus, und Practicus zu Naumburg, Neue Auszüge aus Dissertationen für Wundärzte“ 1782, Bd. 15.

No. XXIII. Instruction vor die Hebammen in den kleinen Staedten Und auf dem Platten Lande 1778, „Register über die Königl. Preuss. und Kurfürstlich Brandenburgische in den Jahren 1776, 1777, 1778, 1779, und 1780. Ergangene Edikte, Patente, Mandate und Haupt-Verordnungen” s.d., kol. 3553-3556.

Pękacka-Falkowska K., Dyscyplinować i pomagać - toruńskie akuszerki miejskie w XVIII w. (kilka uwag na marginesie przysiag i porzadków akuszerskich), „Medycyna Nowożytna” 2013, t. 19, nr 2.

Rezensionen, „Archiv der medizinischen Polizei und der gemeinnützigen Arzneikund" 1785, Bd. 3.

Richter W.M. von, Geschichte der Medicin in Russland, Th. 3, gedruckt bei Wsewoloyski, Moskwa 1817.

Schumann E., Geschichte der Naturforschenden Gesellschaft in Danzig 1743-1892: Festschrift zur Feier des 150 jaehrigen Bestehens der Naturforschenden Gesellschaft in Danzig am 2. Januar 1893, Leipzig 1893.

Sokół S., Medycyna w Gdańsku w dobie odrodzenia, Wrocław 1960.

Spitzer B., Der Zweite Rosengarten: Eine Geschichte Der Geburt, Staude 1999.

Waszyński E., Historia położnictwa i ginekologii w Polsce, Wrocław 2000.

Wrześniewska M., Bąk B., Historia zawodu położnej i kształtowanie się opieki okołoporodowej na świecie i w Polsce, „Studia Medyczne" 2012, t. 27.

von Wahrig B., Sohn W. (red.), Zwischen Aufklärung, Policey und Verwaltung. Zur Genese des Medizinalwesens 1750-1850, Wiesbaden 2003. 